\title{
Role of nutrition in performance enhancement and postexercise recovery
}

This article was published in the following Dove Press journal:

Open Access Journal of Sports Medicine

II August 2015

Number of times this article has been viewed

\author{
Kathryn L Beck' \\ Jasmine S Thomson ${ }^{2}$ \\ Richard J Swift ${ }^{1}$ \\ Pamela R von Hurst' \\ 'School of Food and Nutrition, \\ Massey Institute of Food Science and \\ Technology, College of Health, Massey \\ University Albany, Auckland, ${ }^{2}$ School of \\ Food and Nutrition, Massey Institute \\ of Food Science and Technology, \\ College of Health, Massey University \\ Manawatu, Palmerston North, \\ New Zealand
}

\begin{abstract}
A number of factors contribute to success in sport, and diet is a key component. An athlete's dietary requirements depend on several aspects, including the sport, the athlete's goals, the environment, and practical issues. The importance of individualized dietary advice has been increasingly recognized, including day-to-day dietary advice and specific advice before, during, and after training and/or competition. Athletes use a range of dietary strategies to improve performance, with maximizing glycogen stores a key strategy for many. Carbohydrate intake during exercise maintains high levels of carbohydrate oxidation, prevents hypoglycemia, and has a positive effect on the central nervous system. Recent research has focused on athletes training with low carbohydrate availability to enhance metabolic adaptations, but whether this leads to an improvement in performance is unclear. The benefits of protein intake throughout the day following exercise are now well recognized. Athletes should aim to maintain adequate levels of hydration, and they should minimize fluid losses during exercise to no more than $2 \%$ of their body weight. Supplement use is widespread in athletes, with recent interest in the beneficial effects of nitrate, beta-alanine, and vitamin D on performance. However, an unregulated supplement industry and inadvertent contamination of supplements with banned substances increases the risk of a positive doping result. Although the availability of nutrition information for athletes varies, athletes will benefit from the advice of a registered dietician or nutritionist.
\end{abstract}

Keywords: nutrition, diet, sport, athlete, supplements, hydration

\section{Introduction to the importance and influence of nutrition on exercise}

Nutrition is increasingly recognized as a key component of optimal sporting performance, with both the science and practice of sports nutrition developing rapidly. ${ }^{1}$ Recent studies have found that a planned scientific nutritional strategy (consisting of fluid, carbohydrate, sodium, and caffeine) compared with a self-chosen nutritional strategy helped nonelite runners complete a marathon run faster ${ }^{2}$ and trained cyclists complete a time trial faster. ${ }^{3}$ Whereas training has the greatest potential to increase performance, it has been estimated that consumption of a carbohydrate-electrolyte drink or relatively low doses of caffeine may improve a $40 \mathrm{~km}$ cycling time trial performance by $32-42$ and 55-84 seconds, respectively. ${ }^{4}$

Evidence supports a range of dietary strategies in enhancing sports performance. It is likely that combining several strategies will be of greater benefit than one strategy in isolation. ${ }^{5}$ Dietary strategies to enhance performance include optimizing intakes of macronutrients, micronutrients, and fluids, including their composition and spacing throughout the day. The importance of individualized or personalized dietary advice
Correspondence: Kathryn L Beck School of Food and Nutrition, Massey Institute of Food Science and Technology, College of Health, Massey University Albany, Private Bag 102 904, North Shore City 0745 , Auckland, New Zealand Tel +649213 6662

Email k.I.beck@massey.ac.nz (c) (i) 2015 Beck et al. This work is published by Dove Medical Press Limited, and licensed under Creative Commons Attribution - Non Commercial (unported, v3.0) License. The full terms of the License are available at http://creativecommons.org/licenses/by-nc/3.0/. Non-commercial uses of the work are permitted without any further permission from Dove Medical Press Limited, provided the work is properly attributed. Permissions beyond the scope of the License are administered by Dove Medical Press Limited. Information on how to request permission may be found at: http://www.dovepress.com/permissions.php 
is becoming increasingly recognized, ${ }^{6}$ with dietary strategies varying according to the individual athlete's sport, personal goals, and practicalities (eg, food preferences). "Athlete" includes individuals competing in a range of sport types, such as strength and power (eg, weight-lifting), team (eg, football), and endurance (eg, marathon running). The use of dietary supplements can enhance performance, provided these are used appropriately. This manuscript provides an overview of dietary strategies used by athletes, the efficacy of these strategies, availability of nutrition information to athletes, and risks associated with dietary supplement intake.

\section{Review of diet strategies employed by athletes \\ Maximizing muscle glycogen stores prior to exercise}

Carbohydrate loading aims to maximize an athlete's muscle glycogen stores prior to endurance exercise lasting longer than 90 minutes. Benefits include delayed onset of fatigue (approximately 20\%) and improvement in performance of 2\%-3\%. ${ }^{7}$ Initial protocols involved a depletion phase (3 days of intense training and low carbohydrate intake) followed by a loading phase ( 3 days of reduced training and high carbohydrate intake). ${ }^{8,9}$ Further research showed muscle glycogen concentrations could be enhanced to a similar level without the glycogen-depletion phase, ${ }^{10}$ and more recently, that 24 hours may be sufficient to maximize glycogen stores. ${ }^{11,12}$ Current recommendations suggest that for sustained or intermittent exercise longer than 90 minutes, athletes should consume $10-12 \mathrm{~g}$ of carbohydrate per kg of body mass (BM) per day in the 36-48 hours prior to exercise. ${ }^{13}$

There appears to be no advantage to increasing preexercise muscle glycogen content for moderate-intensity cycling or running of 60-90 minutes, as significant levels of glycogen remain in the muscle following exercise. ${ }^{7}$ For exercise shorter than 90 minutes, $7-12 \mathrm{~g}$ of carbohydrate $/ \mathrm{kg}$ of BM should be consumed during the 24 hours preceding. ${ }^{13}$ Some ${ }^{14,15}$ but not all ${ }^{16}$ studies have shown enhanced performance of intermittent high-intensity exercise of 60-90 minutes with carbohydrate loading.

Carbohydrate eaten in the hours prior to exercise (compared with an overnight fast) has been shown to increase muscle glycogen stores and carbohydrate oxidation, ${ }^{17}$ extend cycle time to exhaustion, ${ }^{5}$ and improve exercise performance. ${ }^{5,18}$ Specific recommendations for exercise of longer than 60 minutes include $1-4 \mathrm{~g}$ of carbohydrate $/ \mathrm{kg}$ of $\mathrm{BM}$ in the 1-4 hours prior. ${ }^{13}$ Most studies have not found improvements in performance from consuming low glycemic index (GI) foods prior to exercise. ${ }^{19}$ Any metabolic or performance effects from low GI foods appear to be attenuated when carbohydrate is consumed during exercise. ${ }^{20,21}$

\section{Carbohydrate intake during the event}

Carbohydrate ingestion has been shown to improve performance in events lasting approximately 1 hour. ${ }^{6}$ A growing body of evidence also demonstrates beneficial effects of a carbohydrate mouth rinse on performance. ${ }^{22}$ It is thought that receptors in the oral cavity signal to the central nervous system to positively modify motor output. ${ }^{23}$

In longer events, carbohydrate improves performance primarily by preventing hypoglycemia and maintaining high levels of carbohydrate oxidation. ${ }^{6}$ The rate of exogenous carbohydrate oxidation is limited by the small intestine's ability to absorb carbohydrate. ${ }^{6}$ Glucose is absorbed by the sodiumdependent transporter (SGLT1), which becomes saturated with an intake of approximately $1 \mathrm{~g} /$ minute. The simultaneous ingestion of fructose (absorbed via glucose transporter 5 [GLUT5]), enables oxidation rates of approximately 1.3 $\mathrm{g} /$ minute, ${ }^{24}$ with performance benefits apparent in the third hour of exercise. ${ }^{6}$ Recommendations reflect this, with $90 \mathrm{~g}$ of carbohydrate from multiple sources recommended for events longer than 2.5 hours, and $60 \mathrm{~g}$ of carbohydrate from either single or multiple sources recommended for exercise of 2-3 hours' duration (Table 1). For slower athletes exercising at a lower intensity, carbohydrate requirements will be less due to lower carbohydrate oxidation. ${ }^{6}$ Daily training with high carbohydrate availability has been shown to increase exogenous carbohydrate oxidation rates. ${ }^{25}$

\section{The "train-low, compete-high" approach}

The "train-low, compete-high" concept is training with low carbohydrate availability to promote adaptations such as

Table I Carbohydrate recommendations for well-trained athletes during exercise

\begin{tabular}{lll}
\hline $\begin{array}{l}\text { Exercise } \\
\text { duration }\end{array}$ & Example & $\begin{array}{l}\text { Recommended } \\
\text { carbohydrate } \\
\text { intake per hour }\end{array}$ \\
\hline $30-75$ & $\begin{array}{l}\text { Sprint triathlon }(750 \mathrm{~m} \mathrm{swim}, \\
20 \mathrm{~km} \text { cycle, } 5 \mathrm{~km} \text { run })\end{array}$ & $\begin{array}{l}\text { Small amounts or } \\
\text { mouth rinse }\end{array}$ \\
minutes & $\begin{array}{l}\text { Netball }(4 \times 15 \text {-minute quarters }) \\
\text { Soccer/football }-2 \times 45 \text {-minute }\end{array}$ & $30 \mathrm{~g}^{\mathrm{a}}$ \\
& $\begin{array}{l}\text { halves } \\
2-3 \text { hours }\end{array}$ & $60 \mathrm{~g}^{\mathrm{a}}$ \\
$>2.5$ hours & $\begin{array}{l}\text { Marathon run }(42.2 \mathrm{~km} \mathrm{run}) \\
\text { Half ironman triathlon }(1.9 \mathrm{~km}\end{array}$ & $90 \mathrm{~g}^{\mathrm{b}}$ \\
& swim, $90 \mathrm{~km}$ cycle, $21.1 \mathrm{~km}$ run $)$ & \\
\hline
\end{tabular}

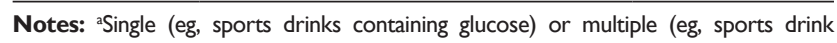

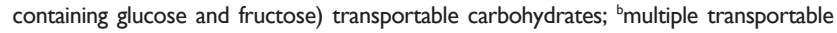
carbohydrates only. Adapted from Jeukendrup A. A step towards personalized sports nutrition: carbohydrate intake during exercise. Sports Med. 2014;44 Suppl I:S25-S33. ${ }^{6}$ 
enhanced activation of cell-signaling pathways, increased mitochondrial enzyme content and activity, enhanced lipid oxidation rates, and hence improved exercise capacity. ${ }^{26}$ However, there is no clear evidence that performance is improved with this approach. ${ }^{27}$ For example, when highly trained cyclists were separated into once-daily (train-high) or twice-daily (train-low) training sessions, increases in resting muscle glycogen content were seen in the low-carbohydrateavailability group, along with other selected training adaptations. ${ }^{28}$ However, performance in a 1-hour time trial after 3 weeks of training was no different between groups. Other research has produced similar results. ${ }^{29}$ Different strategies have been suggested (eg, training after an overnight fast, training twice per day, restricting carbohydrate during recovery), ${ }^{26}$ but further research is needed to establish optimal dietary periodization plans. ${ }^{27}$

\section{Fat as a fuel during endurance exercise}

There has been a recent resurgence of interest in fat as a fuel, particularly for ultraendurance exercise. A high-carbohydrate strategy inhibits fat utilization during exercise, ${ }^{30}$ which may not be beneficial due to the abundance of energy stored in the body as fat. Creating an environment that optimizes fat oxidation potentially occurs when dietary carbohydrate is reduced to a level that promotes ketosis. ${ }^{31}$ However, this strategy may impair performance of high-intensity activity, by contributing to a reduction in pyruvate dehydrogenase activity and glycogenolysis. ${ }^{32}$ The lack of performance benefits seen in studies investigating "high-fat" diets may be attributed to inadequate carbohydrate restriction and time for adaptation. ${ }^{31}$ Research into the performance effects of high fat diets continues.

\section{Protein}

While protein consumption prior to and during endurance and resistance exercise has been shown to enhance rates of muscle protein synthesis (MPS), a recent review found protein ingestion alongside carbohydrate during exercise does not improve time-trial performance when compared with the ingestion of adequate amounts of carbohydrate alone. ${ }^{33}$

\section{Fluid and electrolytes}

The purpose of fluid consumption during exercise is primarily to maintain hydration and thermoregulation, thereby benefiting performance. Evidence is emerging on increased risk of oxidative stress with dehydration. ${ }^{34}$ Fluid consumption prior to exercise is recommended to ensure that the athlete is well-hydrated prior to commencing exercise. ${ }^{35}$ In addition, carefully planned hyperhydration (fluid overloading) prior to an event may reset fluid balance and increase fluid retention, and consequently improve heat tolerance. ${ }^{36}$ However, fluid overloading may increase the risk of hyponatremia ${ }^{37}$ and impact negatively on performance due to feelings of fullness and the need to urinate.

Hydration requirements are closely linked to sweat loss, which is highly variable $(0.5-2.0 \mathrm{~L} /$ hour $)$ and dependent on type and duration of exercise, ambient temperature, and athletes' individual characteristics. ${ }^{35}$ Sodium losses linked to high temperature can be substantial, and in events of long duration or in hot temperatures, sodium must be replaced along with fluid to reduce risk of hyponatremia. ${ }^{35}$

It has long been suggested that fluid losses greater than $2 \%$ of BM can impair performance, ${ }^{35}$ but there is controversy over the recommendation that athletes maintain BM by fluid ingestion throughout an event. ${ }^{37}$ Well-trained athletes who "drink to thirst" have been found to lose as much as $3.1 \%$ of $\mathrm{BM}$ with no impairment of performance in ultraendurance events. ${ }^{38}$ Ambient temperature is important, and a review illustrated that exercise performance was preserved if loss was restricted to $1.8 \%$ and $3.2 \%$ of BM in hot and temperate conditions, respectively. ${ }^{39}$

\section{Dietary supplementation: nitrates, beta-alanine, and vitamin $D$}

Performance supplements shown to enhance performance include caffeine, beetroot juice, beta-alanine (BA), creatine, and bicarbonate. ${ }^{40}$ Comprehensive reviews on other supplements including caffeine, creatine, and bicarbonate can be found elsewhere. ${ }^{41}$ In recent years, research has focused on the role of nitrate, $\mathrm{BA}$, and vitamin $\mathrm{D}$ and performance. Nitrate is most commonly provided as sodium nitrate or beetroot juice. ${ }^{42}$ Dietary nitrates are reduced (in mouth and stomach) to nitrites, and then to nitric oxide. During exercise, nitric oxide potentially influences skeletal muscle function through regulation of blood flow and glucose homeostasis, as well as mitochondrial respiration. ${ }^{43}$ During endurance exercise, nitrate supplementation has been shown to increase exercise efficiency $\left(4 \%-5 \%\right.$ reduction in $\mathrm{VO}_{2}$ at a steady state; $0.9 \%$ improvement in time trials), reduce fatigue, and attenuate oxidative stress. ${ }^{42}$ Similarly, a $4.2 \%$ improvement in performance was shown in a test designed to simulate a football game. ${ }^{44}$

$\mathrm{BA}$ is a precursor of carnosine, which is thought to have a number of performance-enhancing functions including the reduction of acidosis, regulation of calcium, and antioxidant properties. ${ }^{45}$ Supplementation with BA has been shown to 
augment intracellular carnosine concentration. ${ }^{45}$ A systematic review concluded that $\mathrm{BA}$ may increase power output and working capacity and decrease feelings of fatigue, but that there are still questions about safety. The authors suggest caution in the use of BA as an ergogenic aid. ${ }^{46}$

Vitamin D is essential for the maintenance of bone health and control of calcium homeostasis, but is also important for muscle strength, ${ }^{47,48}$ regulation of the immune system, ${ }^{49}$ and cardiovascular health. ${ }^{50}$ Thus inadequate vitamin D status has potential implications for the overall health of athletes and performance. A recent review found that the vitamin D status of most athletes reflects that of the population in their locality, with lower levels in winter, and athletes who train predominantly indoors are at greater risk of deficiency. ${ }^{51}$ There are no dietary vitamin D recommendations for athletes; however, for muscle function, bone health, and avoidance of respiratory infections, current evidence supports maintenance of serum 25-hydroxyvitamin D (circulating form) concentrations of $80-100 \mathrm{nmol} / \mathrm{L} .{ }^{51}$

\section{Diets specific for postexercise}

Recovery from a bout of exercise is integral to the athlete's training regimen. Without adequate recovery of carbohydrate, protein, fluids, and electrolytes, beneficial adaptations and performance may be hampered.

\section{Muscle glycogen synthesis}

Consuming carbohydrates immediately postexercise to coincide with the initial rapid phase of glycogen synthesis has been used as a strategy to maximize rates of muscle glycogen synthesis. An early study found delaying feeding by 2 hours after glycogen-depleting cycling exercise reduced glycogen synthesis rates. ${ }^{52}$ However the importance of this early enhanced rate of glycogen synthesis has been questioned in the context of extended recovery periods with sufficient carbohydrate consumption. Enhancing the rate of glycogen synthesis with immediate carbohydrate consumption after exercise appears most relevant when the next exercise session is within 8 hours of the first. ${ }^{53,54}$ Feeding frequency is also irrelevant with extended recovery; by 24 hours postexercise, consumption of carbohydrate as four large meals or 16 small snacks had comparable effects on muscle glycogen storage. ${ }^{55}$

With less than 8 hours between exercise sessions, it is recommended that for maximal glycogen synthesis, $1.0-1.2 \mathrm{~g} / \mathrm{kg} /$ hour is consumed for the first 4 hours, followed by resumption of daily carbohydrate requirements. ${ }^{13}$ Additional protein has been shown to enhance glycogen synthesis rates when carbohydrate intake is suboptimal. ${ }^{56}$ The consumption of moderate to high GI foods postexercise is recommended; ${ }^{13}$ however, when either a high-GI or low-GI meal was consumed after glycogen-depleting exercise, no performance differences were seen in a $5 \mathrm{~km}$ cycling time trial 3 hours later. ${ }^{57}$

\section{Muscle protein synthesis}

An acute bout of intense endurance or resistance exercise can induce a transient increase in protein turnover, and, until feeding, protein balance remains negative. Protein consumption after exercise enhances MPS and net protein balance, ${ }^{58}$ predominantly by increasing mitochondrial protein fraction with endurance training, and myofibrillar protein fraction with resistance training. ${ }^{59}$

Only a few studies have investigated the effect of timing of protein intake postexercise. No significant difference in MPS was observed over 4 hours postexercise when a mixture of essential amino acids and sucrose was fed 1 hour versus 3 hours after resistance exercise. ${ }^{60}$ Conversely, when a protein and carbohydrate supplement was provided immediately versus 3 hours after cycling exercise, leg protein synthesis increased threefold over 3 hours. ${ }^{61} \mathrm{~A}$ meta-analysis found timed postexercise protein intake becomes less important with longer recovery periods and adequate protein intake, ${ }^{62}$ at least for resistance training.

Dose-response studies suggest approximately $20 \mathrm{~g}$ of high-quality protein is sufficient to maximize MPS at rest, ${ }^{63}$ following resistance, ${ }^{63,64}$ and after high-intensity aerobic exercise. ${ }^{65}$ Rate of MPS has been found to approximately triple 45-90 minutes after protein consumption at rest, and then return to baseline levels, even with continued availability of circulating essential amino acids (termed the "muscle full" effect). ${ }^{66}$ Since exercise-induced protein synthesis is elevated for 24-48 hours following resistance exercise ${ }^{67}$ and 24-28 hours following high-intensity aerobic exercise, ${ }^{68}$ and feeding protein postexercise has an additive effect, ${ }^{58,64}$ then multiple feedings over the day postexercise might maximize muscle growth. In fact, feeding $20 \mathrm{~g}$ of whey protein every 3 hours was subsequently found to maximally stimulate muscle myofibrillar protein synthesis following resistance exercise. ${ }^{69,70}$

In resistance training, where postexercise intake of protein was balanced by protein intake later in the day, increased adaptation of muscle hypertrophy resulted in equivocal strength performance effects. ${ }^{71,72}$ Most studies have not found a subsequent benefit to aerobic performance with postexercise protein consumption. ${ }^{73,74}$ However, in two 
well-controlled studies in which postexercise protein intake was balanced by protein intake later in the day, improvements were seen in cycling time to exhaustion ${ }^{75}$ and in cycling sprint performance. $^{76}$

\section{Fluids and electrolyte balance}

Fluid and electrolyte replacement after exercise can be achieved through resuming normal hydration practices. However, when euhydration is needed within 24 hours or substantial body weight has been lost ( $>5 \%$ of BM), a more structured response may be warranted to replace fluids and electrolytes. ${ }^{77}$

\section{Availability of nutritional information to athletes at varying levels}

The availability of nutrition information for athletes varies. Younger or recreational athletes are more likely to receive generalized nutritional information of poorer quality from individuals such as coaches. ${ }^{78}$ Elite athletes are more likely to have access to specialized sports-nutrition input from qualified professionals. A range of sports science and medicine support systems are in place in different countries to assist elite athletes, ${ }^{1}$ and nutrition is a key component of these services. Some countries have nutrition programs embedded within sports institutes (eg, Australia) or alternatively have National Olympic Committees that support nutrition programs (eg, United States of America). ${ }^{1}$ However, not all athletes at the elite level have access to sports-nutrition services. This may be due to financial constraints of the sport, geographical issues, and a lack of recognition of the value of a sports-nutrition service. ${ }^{78}$

Athletes eat several times per day, with snacks contributing to energy requirements. ${ }^{79}$ Dietary intake differs across sports, with endurance athletes more likely to achieve energy and carbohydrate requirements compared to athletes in weight-conscious sports. ${ }^{79}$ A review found daily intakes of carbohydrate were $7.6 \mathrm{~g} / \mathrm{kg}$ and $5.7 \mathrm{~g} / \mathrm{kg}$ of BM for male and female endurance athletes, respectively. ${ }^{80}$ Ten elite Kenyan runners met macronutrient recommendations but not guidelines for fluid intake. ${ }^{81}$ A review of fluid strategies showed a wide variability of intake across sports, with several factors influencing intake, many outside the athlete's control. ${ }^{82}$

Nutrition information may be delivered to athletes by a range of people (dietitians, nutritionists, medical practitioners, sports scientists, coaches, trainers) and from a variety of sources (nutrition education programs, sporting magazines, the media and Internet). ${ }^{83}$ Of concern is the provision of nutrition advice from outside various professional's scope of practice. For example, in Australia 88\% of registered exercise professionals provided nutrition advice, despite many not having adequate nutrition training. ${ }^{84} \mathrm{~A}$ study of Canadian high-performance athletes from 34 sports found physicians ranked eighth and dietitians, 16th as choice of source of dietary supplement information. ${ }^{85}$

\section{Risks of contravening the doping regulations}

Supplement use is widespread in athletes. ${ }^{86,87}$ For example, $87.5 \%$ of elite athletes in Australia used dietary supplements ${ }^{88}$ and $87 \%$ of Canadian high-performance athletes took dietary supplements within the past 6 months $^{85}$ (Table 2). It is difficult to compare studies due to differences in the criteria used to define dietary supplements, variations in assessing supplement intake, and disparities in the populations studied. ${ }^{85}$

Athletes take supplements for many reasons, including for proposed performance benefits, for prevention or treatment of a nutrient deficiency, for convenience, or due to fear of "missing out" by not taking a particular supplement. ${ }^{41}$

The potential benefits (eg, improved performance) of taking a dietary supplement must outweigh the risks. ${ }^{86,87}$ There are few permitted dietary supplements available that have an ergogenic effect. ${ }^{87,89}$ Dietary supplementation cannot compensate for poor food choices. ${ }^{87}$ Other concerns include lack of efficacy, safety issues (toxicity, medical concerns), negative nutrient interactions, unpleasant side effects, ethical issues, financial expense, and lack of quality control. ${ }^{41,86,87}$ Of major concern, is the consumption of prohibited substances by the World Anti-Doping Agency (WADA).

Inadequate regulation in the supplement industry (compounded by widespread Internet sales) makes it difficult for athletes to choose supplements wisely. ${ }^{41,86,87}$ In 2000-2001, a study of 634 different supplements from 13 countries found that $94(14.8 \%)$ contained undeclared steroids, banned by WADA..$^{90}$ Many contaminated supplements were routinely used by athletes (eg, vitamin and mineral supplements). ${ }^{86}$ Several studies have confirmed these findings. ${ }^{41,86,89}$

A positive drug test in an athlete can occur with even a minute quantity of a banned substance. ${ }^{41,87}$ WADA maintains a "strict liability" policy, whereby every athlete is responsible for any substance found in their body regardless of how it got there. ${ }^{41,86,87,89}$ The World Anti-Doping Code (January 1, 2015) does recognize the issue of contaminated supplements. ${ }^{91}$ Whereas the code upholds the principle of strict liability, athletes may receive a lesser ban if they can 
Table 2 Dietary supplement use in high-performing athletes from 2010-2015

\begin{tabular}{|c|c|c|c|}
\hline Author, year & $\begin{array}{l}\text { Athlete population } \\
\text { (sport, level), country }\end{array}$ & Use of DS $\mathbf{S}^{\mathrm{a}}$ & Main reasons for $D S u^{a}$ \\
\hline $\begin{array}{l}\text { Aljaloud and } \\
\text { lbrahim, }{ }^{92} 2013\end{array}$ & $\begin{array}{l}\text { Professional footballers (male, } \\
n=105 \text { ), Saudi Arabia }\end{array}$ & $\begin{array}{l}93.3 \% \text { currently took DS } \\
\text { Sports drinks - } 88.7 \% \text {; vitamin C - } 82.6 \% \text {; } \\
\text { calcium }-68.3 \%\end{array}$ & $\begin{array}{l}\text { Performance }-43.8 \% \text {; improved } \\
\text { health }-32.6 \% \text {; physical } \\
\text { appearance - II. } 2 \%\end{array}$ \\
\hline $\begin{array}{l}\text { Kim et al, }{ }^{93} \\
2013\end{array}$ & $\begin{array}{l}\text { National judo team members } \\
\text { (male, } n=107 \text { and female, } n=65 \text { ), } \\
\text { Korea and Japan }\end{array}$ & $\begin{array}{l}59 \% \text { of Korean athletes and } 61 \% \text { of } \\
\text { Japanese athletes took DS }\end{array}$ & $\begin{array}{l}\text { Korean: improve muscle strength - } \\
45 \% \text {; improve energy - } 18 \% \\
\text { Japanese: maintain health - } 32 \% \text {; } \\
\text { improve performance }-26 \%\end{array}$ \\
\hline $\begin{array}{l}\text { Diehl et al, }{ }^{94} \\
2012\end{array}$ & $\begin{array}{l}\text { Elite adolescent athletes from } \\
5 \mathrm{I} \text { current Olympic sports (male } \\
\text { and female, } n=I \mid 38 \text { ), Germany }\end{array}$ & $\begin{array}{l}91.1 \% \text { consumed at least one DS at least } \\
\text { once per month } \\
\text { Magnesium - } 68.6 \% \text {; dextrose }-64.0 \% \text {; } \\
\text { energy drinks - } 63.9 \% \\
26.8 \% \text { consumed at least one DS daily } \\
\text { Magnesium - } 82.9 \% \text {; vitamin C - } 76.2 \% \text {; } \\
\text { iron }-70.3 \%\end{array}$ & $\mathrm{n} / \mathrm{a}$ \\
\hline $\begin{array}{l}\text { Lun et al, } 85 \\
2012\end{array}$ & $\begin{array}{l}\text { Athletes affiliated with Canadian } \\
\text { Sport Centres from } 34 \text { sports } \\
\text { (male and female, } n=440 \text { ), Canada }\end{array}$ & $\begin{array}{l}87 \% \text { declared having taken a DS within } \\
\text { past } 6 \text { months } \\
\text { Sports drinks - } 24.1 \% \text {; multivitamins and } \\
\text { minerals - } 16.1 \% \text {; carbohydrate sport } \\
\text { bars - II.0\% }\end{array}$ & $\begin{array}{l}\text { Health maintenance/prevent } \\
\text { nutritional deficiency }-30.2 \% \text {; } \\
\text { increase energy - } 20.5 \% \text {; exercise } \\
\text { recovery - } 15.6 \%\end{array}$ \\
\hline $\begin{array}{l}\text { Rodek et al, }{ }^{95} \\
2012\end{array}$ & $\begin{array}{l}\text { National representative sailors } \\
\text { (male, } \mathrm{n}=39 \text { and female, } \mathrm{n}=44) \text {, } \\
\text { Croatia }\end{array}$ & $\begin{array}{l}38.6 \% \text { consume DS daily } \\
38.6 \% \text { consume DS (but not regularly) } \\
\text { Vitamins and minerals - } 40.9 \% \text {; energy } \\
\text { bars - } 38.6 \% \text {; protein/amino acids - } \\
34.1 \% \text {; isotonic drinks - } 34.1 \%\end{array}$ & $\mathrm{n} / \mathrm{a}$ \\
\hline $\begin{array}{l}\text { Heikkinen et al, }{ }^{96} \\
20 \mathrm{II}\end{array}$ & $\begin{array}{l}\text { Olympic athletes from } 31 \text { sports } \\
\text { (male and female, } n=446 \text { in } 2002 \text {, } \\
n=372 \text { in } 2008 / 2009 \text { ), Finland }\end{array}$ & $\begin{array}{l}2002: 81 \% \text { reported DS use in the past } \\
\text { I } 2 \text { months } \\
\text { Multivitamins }-54 \% \text {; protein }-47 \% \text {; } \\
\text { vitamin C }-28 \% \\
2008 / 2009: 73 \% \text { reported DS use in the } \\
\text { past } 12 \text { months } \\
\text { Multivitamins }-57 \% \text {; protein }-38 \% \text {; } \\
\text { vitamin C }-24 \%\end{array}$ & $\mathrm{n} / \mathrm{a}$ \\
\hline $\begin{array}{l}\text { Kim et al, }{ }^{97} \\
2011\end{array}$ & $\begin{array}{l}\text { National Sport University athletes } \\
\text { from } 2 \text { I sports (male and female, } \\
n=479 \text { ), Korea }\end{array}$ & $\begin{array}{l}46 \% \text { used DS and } 28 \% \text { used TCM } \\
\text { supplements within the past year } \\
\text { DS: multivitamins }-70.0 \% \text {; } \\
\text { vitamin C }-37.7 \% \text {; sports drinks - } 18.4 \% \\
\text { TCM supplements: red ginseng }-70.2 \% \text {; } \\
\text { mixed TCM }-44.7 \% \text {; ginseng - } 10.5 \%\end{array}$ & $\begin{array}{l}\text { Energy supplement }-33.3 \% \text {; } \\
\text { increase in strength, muscle mass, } \\
\text { and muscle power - } 17.4 \% \text {; health } \\
\text { maintenance - } 14.6 \%\end{array}$ \\
\hline $\begin{array}{l}\text { Dascombe et al, }{ }^{88} \\
2010\end{array}$ & $\begin{array}{l}\text { State-based sports institute } \\
\text { athletes from seven sports (male } \\
\text { and female, } n=72 \text { ), Australia }\end{array}$ & $\begin{array}{l}87.5 \% \text { reported using at least one DS } \\
\text { Minerals }-45.8 \% \text {; vitamins }-43.1 \% \text {; } \\
\text { iron }-30.6 \%\end{array}$ & $\begin{array}{l}\text { Maintain health; dietary } \\
\text { routine; boost immunity; peer } \\
\text { recommendations }\end{array}$ \\
\hline $\begin{array}{l}\text { De Silva et al, }{ }^{98} \\
2010\end{array}$ & $\begin{array}{l}\text { National-level athletes (male and } \\
\text { female, } n=I \mid 3 \text { ), Sri Lanka }\end{array}$ & $\begin{array}{l}\text { 93.8\% reported using DS } \\
\text { Multivitamin preparations, vitamin E, } \\
\text { calcium, energy foods and drinks, creatine }\end{array}$ & $\begin{array}{l}\text { Enhance performance }-79.2 \% \text {; } \\
\text { improve general health status - } \\
19.8 \%\end{array}$ \\
\hline
\end{tabular}

Note: ${ }^{\text {aTop }} 3$ supplements, reasons for use, and sources of information provided where available.

Abbreviations: DS, dietary supplement; n/a, not available; TCM, Traditional Chinese Medicine.

show "no significant fault" to demonstrate they did not intend to cheat. The updated code imposes longer bans on those who cheat intentionally, includes athlete support personnel (eg, coaches, medical staff), and has an increased focus on antidoping education. ${ }^{91,99}$

In an effort to educate athletes about sports-supplement use, the Australian Institute of Sport's sports-supplement program categorizes supplements according to evidence of efficacy in performance and risk of doping outcome. ${ }^{40}$ Category A supplements have sound evidence for use and include sports foods, medical supplements, and performance supplements. Category D supplements should not be used by athletes, as they are banned or are at high risk for contamination. These include stimulants, prohormones and hormone boosters, growth hormone releasers, peptides, glycerol, and colostrum. ${ }^{40}$ 


\section{Conclusion}

Athletes are always looking for an edge to improve their performance, and there are a range of dietary strategies available. Nonetheless, dietary recommendations should be individualized for each athlete and their sport and provided by an appropriately qualified professional to ensure optimal performance. Dietary supplements should be used with caution and as part of an overall nutrition and performance plan.

\section{Disclosure}

The authors report no conflicts of interest in this work.

\section{References}

1. Burke LM, Meyer NL, Pearce J. National nutritional programs for the 2012 London Olympic Games: A systematic approach by three different countries. In: van Loon LJC, Meeusen R, editors. Limits of Human Endurance. Nestle Nutrition Institute Workshop Series, volume 76. Vevey, Switzerland: Nestec Ltd; 2013:103-120.

2. Hansen EA, Emanuelsen A, Gertsen RM, Sørensen SSR. Improved marathon performance by in-race nutritional strategy intervention. Int J Sport Nutr Exerc Metab. 2014;24(6):645-655.

3. Hottenrott K, Hass E, Kraus M, Neumann G, Steiner M, Knechtle B. A scientific nutrition strategy improves time trial performance by $\approx 6 \%$ when compared with a self-chosen nutrition strategy in trained cyclists: a randomized cross-over study. Appl Physiol Nutr Metab. 2012; 37(4):637-645.

4. Jeukendrup AE, Martin J. Improving cycling performance: how should we spend our time and money. Sports Med. 2001;31(7):559-569.

5. Wright DA, Sherman WM, Dernbach AR. Carbohydrate feedings before, during, or in combination improve cycling endurance performance. J Appl Physiol (1985). 1991;71(3):1082-1088.

6. Jeukendrup A. A step towards personalized sports nutrition: carbohydrate intake during exercise. Sports Med. 2014;44 Suppl 1: S25-S33.

7. Hawley JA, Schabort EJ, Noakes TD, Dennis SC. Carbohydrateloading and exercise performance. An update. Sports Med. 1997;24(2): 73-81.

8. Bergström J, Hermansen L, Hultman E, Saltin B. Diet, muscle glycogen and physical performance. Acta Physiol Scand. 1967;71(2):140-150.

9. Karlsson J, Saltin B. Diet, muscle glycogen, and endurance performance. J Appl Physiol. 1971;31(2):203-206.

10. Sherman WM, Costill DL, Fink WJ, Miller JM. Effect of exercise-diet manipulation on muscle glycogen and its subsequent utilization during performance. Int J Sports Med. 1981;2(2):114-118.

11. Bussau VA, Fairchild TJ, Rao A, Steele P, Fournier PA. Carbohydrate loading in human muscle: an improved 1 day protocol. Eur J Appl Physiol. 2002;87(3):290-295.

12. Fairchild TJ, Fletcher S, Steele P, Goodman C, Dawson B, Fournier PA. Rapid carbohydrate loading after a short bout of near maximal-intensity exercise. Med Sci Sports Exerc. 2002;34(6):980-986.

13. Burke LM, Hawley JA, Wong SH, Jeukendrup AE. Carbohydrates for training and competition. J Sports Sci. 2011;29 Suppl 1:S17-S27.

14. Raman A, Macdermid PW, Mündel T, Mann M, Stannard SR. The effects of carbohydrate loading 48 hours before a simulated squash match. Int J Sport Nutr Exerc Metab. 2014;24(2):157-165.

15. Balsom PD, Wood K, Olsson P, Ekblom B. Carbohydrate intake and multiple sprint sports: with special reference to football (soccer). Int $J$ Sports Med. 1999;20(1):48-52.

16. Abt G, Zhou S, Weatherby R. The effect of a high-carbohydrate diet on the skill performance of midfield soccer players after intermittent treadmill exercise. J Sci Med Sport. 1998;1(4):203-212.
17. Coyle EF, Coggan AR, Hemmert MK, Lowe RC, Walters TJ. Substrate usage during prolonged exercise following a preexercise meal. $\mathrm{J} \mathrm{Appl}$ Physiol (1985). 1985;59(2):429-433.

18. Neufer PD, Costill DL, Flynn MG, Kirwan JP, Mitchell JB, Houmard J. Improvements in exercise performance: effects of carbohydrate feedings and diet. J Appl Physiol (1985). 1987;62(3):983-988.

19. Burke LM, Collier GR, Hargreaves M. Glycemic index - a new tool in sport nutrition? Int J Sport Nutr. 1998;8(4):401-415.

20. Burke LM, Claassen A, Hawley JA, Noakes TD. Carbohydrate intake during prolonged cycling minimizes effect of glycemic index of preexercise meal. J Appl Physiol (1985). 1998;85(6):2220-2226.

21. Wong SH, Chan OW, Chen YJ, Hu HL, Lam CW, Chung PK. Effect of preexercise glycemic-index meal on running when $\mathrm{CHO}$-electrolyte solution is consumed during exercise. Int J Sport Nutr Exerc Metab. 2009;19(3):222-242.

22. Burke LM, Maughan RJ. The Governor has a sweet tooth - mouth sensing of nutrients to enhance sports performance. Eur J Sport Sci. 2015;15(1):29-40.

23. Gant N, Stinear CM, Byblow WD. Carbohydrate in the mouth immediately facilitates motor output. Brain Res. 2010;1350:151-158.

24. Jentjens RL, Moseley L, Waring RH, Harding LK, Jeukendrup AE. Oxidation of combined ingestion of glucose and fructose during exercise. J Appl Physiol (1985). 2004;96(4):1277-1284.

25. Cox GR, Clark SA, Cox AJ, et al. Daily training with high carbohydrate availability increases exogenous carbohydrate oxidation during endurance cycling. J Appl Physiol (1985). 2010;109(1):126-134.

26. Bartlett JD, Hawley JA, Morton JP. Carbohydrate availability and exercise training adaptation: too much of a good thing? Eur J Sport Sci. 2015;15(1):3-12.

27. Burke LM. Fueling strategies to optimize performance: training high or training low? Scand J Med Sci Sports. 2010;20 Suppl 2:48-58.

28. Yeo WK, Paton CD, Garnham AP, Burke LM, Carey AL, Hawley JA. Skeletal muscle adaptation and performance responses to once a day versus twice every second day endurance training regimens. $J \mathrm{Appl}$ Physiol (1985). 2008;105(5):1462-1470.

29. Morton JP, Croft L, Bartlett JD, et al. Reduced carbohydrate availability does not modulate training-induced heat shock protein adaptations but does upregulate oxidative enzyme activity in human skeletal muscle. J Appl Physiol (1985). 2009;106(5):1513-1521.

30. Horowitz JF, Mora-Rodriguez R, Byerley LO, Coyle EF. Lipolytic suppression following carbohydrate ingestion limits fat oxidation during exercise. Am J Physiol. 1997;273(4 Pt 1):E768-E775.

31. Volek JS, Noakes T, Phinney SD. Rethinking fat as a fuel for endurance exercise. Eur J Sport Sci. 2015;15(1):13-20.

32. Stellingwerff T, Spriet LL, Watt MJ, et al. Decreased PDH activation and glycogenolysis during exercise following fat adaptation with carbohydrate restoration. Am J Physiol Endocrinol Metab. 2006;290(2):E380-E388.

33. van Loon LJ. Is there a need for protein ingestion during exercise? Sports Med. 2014;44 Suppl 1:S105-S111.

34. Hillman AR, Turner MC, Peart DJ, et al. A comparison of hyperhydration versus ad libitum fluid intake strategies on measures of oxidative stress, thermoregulation, and performance. Res Sports Med. 2013;21(4):305-317.

35. Sawka MN, Burke LM, Eichner ER, Maughan RJ, Montain SJ, Stachenfeld NS; American College of Sports Medicine. American College of Sports Medicine position stand. Exercise and fluid replacement. Med Sci Sports Exerc. 2007;39(2):377-390.

36. Kristal-Boneh E, Glusman JG, Shitrit R, Chaemovitz C, Cassuto Y. Physical performance and heat tolerance after chronic water loading and heat acclimation. Aviat Space Environ Med. 1995;66(8):733-738.

37. Noakes TD. Drinking guidelines for exercise: what evidence is there that athletes should drink "as much as tolerable", "to replace the weight lost during exercise" or "ad libitum"? J Sports Sci. 2007;25(7):781-796.

38. Hoffman MD, Stuempfle KJ. Hydration strategies, weight change and performance in a $161 \mathrm{~km}$ ultramarathon. Res Sports Med. 2014;22(3):213-225. 
39. Goulet ED, Aubertin-Leheudre M, Plante GE, Dionne IJ. A metaanalysis of the effects of glycerol-induced hyperhydration on fluid retention and endurance performance. Int J Sport Nutr Exerc Metab. 2007;17(4):391-410.

40. Australian Institute of Sport. ABCD Classification System [webpage on the Internet]. Bruce, Australian Capital Territory: Australian Sports Commission; 2015. Available from: http://www.ausport.gov.au/ais/ nutrition/supplements/classification. Accessed March 24, 2015

41. Burke LM, Castell LM, Stear SJ. BJSM reviews: A-Z of supplements: dietary supplements, sports nutrition foods and ergogenic aids for health and performance Part 1. Br J Sports Med. 2009;43(10):728-729.

42. Hoon MW, Johnson NA, Chapman PG, Burke LM. The effect of nitrate supplementation on exercise performance in healthy individuals: a systematic review and meta-analysis. Int $J$ Sport Nutr Exerc Metab. 2013;23(5):522-532.

43. Jones AM. Dietary nitrate supplementation and exercise performance. Sports Med. 2014;44 Suppl 1:S35-S45.

44. Wylie LJ, Mohr M, Krustrup P, et al. Dietary nitrate supplementation improves team sport-specific intense intermittent exercise performance. Eur J Appl Physiol. 2013;113(7):1673-1684.

45. Blancquaert L, Everaert I, Derave W. Beta-alanine supplementation, muscle carnosine and exercise performance. Curr Opin Clin Nutr Metab Care. 2015;18(1):63-70.

46. Quesnele JJ, Laframboise MA, Wong JJ, Kim P, Wells GD. The effects of beta-alanine supplementation on performance: a systematic review of the literature. Int J Sport Nutr Exerc Metab. 2014;24(1):14-27.

47. Stockton KA, Mengersen K, Paratz JD, Kandiah D, Bennell KL. Effect of vitamin D supplementation on muscle strength: a systematic review and meta-analysis. Osteoporos Int. 2011;22(3):859-871.

48. Girgis CM, Clifton-Bligh RJ, Hamrick MW, Holick MF, Gunton JE. The roles of vitamin D in skeletal muscle: form, function, and metabolism. Endocr Rev. 2013;34(1):33-83.

49. Taylor CE, Camargo CA. Impact of micronutrients on respiratory infections. Nutr Rev. 2011;69(5):259-269.

50. Zittermann A, Prokop S. The role of vitamin D for cardiovascular disease and overall mortality. Adv Exp Med Biol. 2014;810:106-119.

51. von Hurst PR, Beck KL. Vitamin D and skeletal muscle function in athletes. Curr Opin Clin Nutr Metab Care. 2014;17(6):539-545.

52. Ivy JL, Katz AL, Cutler CL, Sherman WM, Coyle EF. Muscle glycogen synthesis after exercise: effect of time of carbohydrate ingestion. J Appl Physiol (1985). 1988;64(4):1480-1485.

53. Parkin JA, Carey MF, Martin IK, Stojanovska L, Febbraio MA. Muscle glycogen storage following prolonged exercise: effect of timing of ingestion of high glycemic index food. Med Sci Sports Exerc. 1997;29(2):220-224.

54. Jensen L, Gejl KD, Ørtenblad N, et al. Carbohydrate restricted recovery from long term endurance exercise does not affect gene responses involved in mitochondrial biogenesis in highly trained athletes. Physiol Rep. 2015;3(2):e12184.

55. Burke LM, Collier GR, Davis PG, Fricker PA, Sanigorski AJ, Hargreaves M. Muscle glycogen storage after prolonged exercise: effect of the frequency of carbohydrate feedings. Am J Clin Nutr. 1996;64(1): 115-119.

56. van Loon LJ, Saris WH, Kruijshoop M, Wagenmakers AJ. Maximizing postexercise muscle glycogen synthesis: carbohydrate supplementation and the application of amino acid or protein hydrolysate mixtures. $\mathrm{Am}$ J Clin Nutr. 2000;72(1):106-111.

57. Brown LJ, Midgley AW, Vince RV, Madden LA, McNaughton LR. High versus low glycemic index 3-h recovery diets following glycogendepleting exercise has no effect on subsequent $5-\mathrm{km}$ cycling time trial performance. J Sci Med Sport. 2013;16(5):450-454.

58. Phillips SM, Van Loon LJ. Dietary protein for athletes: from requirements to optimum adaptation. $J$ Sports Sci. 2011;29 Suppl 1:S29-S38.

59. Wilkinson SB, Phillips SM, Atherton PJ, et al. Differential effects of resistance and endurance exercise in the fed state on signalling molecule phosphorylation and protein synthesis in human muscle. $J$ Physiol. 2008;586(Pt 15):3701-3717.
60. Rasmussen BB, Tipton KD, Miller SL, Wolf SE, Wolfe RR. An oral essential amino acid-carbohydrate supplement enhances muscle protein anabolism after resistance exercise. J Appl Physiol (1985). 2000; 88(2):386-392.

61. Levenhagen DK, Gresham JD, Carlson MG, Maron DJ, Borel MJ, Flakoll PJ. Postexercise nutrient intake timing in humans is critical to recovery of leg glucose and protein homeostasis. Am J Physiol Endocrinol Metab. 2001;280(6):E982-E993.

62. Schoenfeld BJ, Aragon AA, Krieger JW. The effect of protein timing on muscle strength and hypertrophy: a meta-analysis. J Int Soc Sports Nutr. 2013;10(1):53.

63. Witard OC, Jackman SR, Breen L, Smith K, Selby A, Tipton KD. Myofibrillar muscle protein synthesis rates subsequent to a meal in response to increasing doses of whey protein at rest and after resistance exercise. Am J Clin Nutr. 2014;99(1):86-95.

64. Moore DR, Robinson MJ, Fry JL, et al. Ingested protein dose response of muscle and albumin protein synthesis after resistance exercise in young men. Am J Clin Nutr. 2009;89(1):161-168.

65. Rowlands DS, Nelson AR, Phillips SM, et al. Protein-leucine fed dose effects on muscle protein synthesis after endurance exercise. Med Sci Sports Exerc. 2015;47(3):547-555.

66. Atherton PJ, Etheridge T, Watt PW, et al. Muscle full effect after oral protein: time-dependent concordance and discordance between human muscle protein synthesis and mTORC1 signaling. Am J Clin Nutr. 2010;92(5):1080-1088.

67. Phillips SM, Tipton KD, Aarsland A, Wolf SE, Wolfe RR. Mixed muscle protein synthesis and breakdown after resistance exercise in humans. Am J Physiol. 1997;273(1 Pt 1):E99-E107.

68. Di Donato DM, West DW, Churchward-Venne TA, Breen L, Baker SK, Phillips SM. Influence of aerobic exercise intensity on myofibrillar and mitochondrial protein synthesis in young men during early and late postexercise recovery. Am J Physiol Endocrinol Metab. 2014;306(9):E1025-E1032.

69. Areta JL, Burke LM, Ross ML, et al. Timing and distribution of protein ingestion during prolonged recovery from resistance exercise alters myofibrillar protein synthesis. $J$ Physiol. 2013;591(Pt 9):2319-2331.

70. Moore DR, Areta J, Coffey VG, et al. Daytime pattern of post-exercise protein intake affects whole-body protein turnover in resistance-trained males. Nutr Metab (Lond). 2012;9(1):91.

71. Cribb PJ, Hayes A. Effects of supplement timing and resistance exercise on skeletal muscle hypertrophy. Med Sci Sports Exerc. 2006; 38(11):1918-1925.

72. Hoffman JR, Ratamess NA, Tranchina CP, Rashti SL, Kang J, Faigenbaum AD. Effect of protein-supplement timing on strength, power, and body-composition changes in resistance-trained men. Int $J$ Sport Nutr Exerc Metab. 2009;19(2):172-185.

73. Rowlands DS, Wadsworth DP. Effect of high-protein feeding on performance and nitrogen balance in female cyclists. Med Sci Sports Exerc. 2011;43(1):44-53.

74. Nelson AR, Phillips SM, Stellingwerff T, et al. A protein-leucine supplement increases branched-chain amino acid and nitrogen turnover but not performance. Med Sci Sports Exerc. 2012;44(1):57-68.

75. Roy BD, Luttmer K, Bosman MJ, Tarnopolsky MA. The influence of post-exercise macronutrient intake on energy balance and protein metabolism in active females participating in endurance training. Int $J$ Sport Nutr Exerc Metab. 2002;12(2):172-188.

76. Thomson JS, Ali A, Rowlands DS. Leucine-protein supplemented recovery feeding enhances subsequent cycling performance in welltrained men. Appl Physiol Nutr Metab. 2011;36(2):242-253.

77. Shirreffs SM, Sawka MN. Fluid and electrolyte needs for training, competition, and recovery. J Sports Sci. 2011;29 Suppl 1:S39-S46.

78. Zinn C, Schofield G, Wall C. Evaluation of sports nutrition knowledge of New Zealand premier club rugby coaches. Int J Sport Nutr Exerc Metab. 2006;16(2):214-225.

79. Burke LM, Slater G, Broad EM, Haukka J, Modulon S, Hopkins WG. Eating patterns and meal frequency of elite Australian athletes. Int $J$ Sport Nutr Exerc Metab. 2003;13(4):521-538. 
80. Burke LM, Cox GR, Cummings NK, Desbrow B. Guidelines for daily carbohydrate intake: do athletes achieve them? Sports Med. 2001; 31(4):267-299.

81. Beis LY, Willkomm L, Ross R, et al. Food and macronutrient intake of elite Ethiopian distance runners. J Int Soc Sports Nutr. 2011; $8(7): 1-7$.

82. Garth AK, Burke LM. What do athletes drink during competitive sporting activities? Sports Med. 2013;43(7):539-564.

83. Heaney S, O'Connor H, Michael S, Gifford J, Naughton G. Nutrition knowledge in athletes: a systematic review. Int J Sport Nutr Exerc Metab. 2011;21(3):248-261.

84. McKean MR, Slater G, Oprescu F, Burkett BJ. Do the nutrition qualifications and professional practices of registered exercise professionals align? Int J Sport Nutr Exerc Metab. 2015;25(2):154-162.

85. Lun V, Erdman KA, Fung TS, Reimer RA. Dietary supplementation practices in Canadian high-performance athletes. Int J Sport Nutr Exerc Metab. 2012;22(1):31-37.

86. Maughan RJ. Contamination of dietary supplements and positive drug tests in sport. J Sports Sci. 2005;23(9):883-889.

87. Maughan RJ, Greenhaff PL, Hespel P. Dietary supplements for athletes: emerging trends and recurring themes. J Sports Sci. 2011;29 Suppl 1: S57-S66.

88. Dascombe BJ, Karunaratna M, Cartoon J, Fergie B, Goodman C. Nutritional supplementation habits and perceptions of elite athletes within a state-based sporting institute. J Sci Med Sport. 2010;13(2): 274-280.

89. Vernec A, Stear SJ, Burke LM, Castell LM. A-Z of nutritional supplements: dietary supplements, sports nutrition foods and ergogenic aids for health and performance: Part 48. Br J Sports Med. 2013;47(15):998-1000.

90. Geyer H, Parr MK, Mareck U, Reinhart U, Schrader Y, Schänzer W. Analysis of non-hormonal nutritional supplements for anabolicandrogenic steroids - results of an international study. Int J Sports Med. 2004;25(2):124-129.
91. World Anti-Doping Agency. World Anti-Doping Code 2015. Montreal, Quebec: World Anti-Doping Agency; 2015.

92. Aljaloud SO, Ibrahim SA. Use of dietary supplements among professional athletes in Saudi Arabia. J Nutr Metab. 2013;2013:245349.

93. Kim J, Lee N, Lee J, Jung SS, Kang SK, Yoon JD. Dietary supplementation of high-performance Korean and Japanese judoists. Int J Sport Nutr Exerc Metab. 2013;23(2):119-127.

94. Diehl K, Thiel A, Zipfel S, Mayer J, Schnell A, Schneider S. Elite adolescent athletes' use of dietary supplements: characteristics, opinions, and sources of supply and information. Int J Sport Nutr Exerc Metab. 2012;22(3):165-174.

95. Rodek J, Sekulic D, Kondric M. Dietary supplementation and doping-related factors in high-level sailing. J Int Soc Sports Nutr. 2012;9(1):51.

96. Heikkinen A, Alaranta A, Helenius I, Vasankari T. Use of dietary supplements in Olympic athletes is decreasing: a follow-up study between 2002 and 2009. J Int Soc Sports Nutr. 2011;8(1):1.

97. Kim J, Lee N, Kim EJ, Ki SK, Yoon J, Lee MS. Anti-doping education and dietary supplementation practice in Korean elite university athletes. Nutr Res Pract. 2011;5(4):349-356.

98. de Silva A, Samarasinghe Y, Senanayake D, Lanerolle P. Dietary supplement intake in national-level Sri Lankan athletes. Int J Sport Nutr Exerc Metab. 2010;20(1):15-20.

99. World Anti-Doping Agency. Significant Changes Between the 2009 Code and the 2015 Code, Version 4.0. Montreal, Quebec: World Anti-Doping Agency; 2013. Available from https://wada-main-prod.s3.amazonaws. com/wadc-2015-draft-version-4.0-significant-changes-to-2009-en.pdf. Accessed March 24, 2015.
Open Access Journal of Sports Medicine

\section{Publish your work in this journal}

Open Access Journal of Sports Medicine is an international, peer-reviewed, open access journal publishing original research, reports, reviews and commentaries on all areas of sports medicine. The manuscript management system is completely online and includes a very quick and fair peer-review system.

\section{Dovepress}

Visit http://www.dovepress.com/testimonials.php to read real quotes from published authors. 